\title{
Analysis of the expression pattern of the $B C L 11 B$ gene and its relatives in patients with T-cell acute lymphoblastic leukemia
}

\author{
Xin Huang ${ }^{1,2}$, Shaohua Chen ${ }^{1}$, Qi Shen ${ }^{1}$, Lijian Yang ${ }^{1}$, Bo Li ${ }^{1}$, Liye Zhong ${ }^{1,2}$, Suxia Geng ${ }^{2}$, Xin Du ${ }^{2}$, Yangqiu Li ${ }^{1,3^{*}}$
}

\begin{abstract}
Background: In a human T-cell acute lymphoblastic leukemia (T-ALL) cell line (Molt-4), siRNA-mediated suppression of $B C L 11 B$ expression was shown to inhibit proliferation and induce apoptosis, functions which may be related to genes involved in apoptosis (such as TNFSF10 and BCL2L1) and TGF- $\beta$ pathways (such as SPP1and (REBBP).

Methods: The expression levels of the above mentioned genes and their correlation with the BCL11B gene were analyzed in patients with T-ALL using the TaqMan and SYBR Green I real-time polymerase chain reaction technique.

Results: Expression levels of $B C L 11 B, B C L 2 L 1$, and CREBBP mRNA in T-ALL patients were significantly higher than those from healthy controls $(P<0.05)$. In T-ALL patients, the $B C L 11 B$ expression level was negatively correlated with the BCL2L1 expression level $\left(r_{\mathrm{s}}=-0.700 ; P<0.05\right)$, and positively correlated with the SPP1 expression level $\left(r_{\mathrm{s}}=\right.$ $0.683 ; P<0.05)$. In healthy controls, the $B C L 11 B$ expression level did not correlate with the TNFSF10, BCL2L1, SPP1, or CREBBP expression levels.

Conclusions: Over-expression of $B C L 11 B$ might play a role in anti-apoptosis in T-ALL cells through up-regulation of its downstream genes BCL2L1 and CREBBP.
\end{abstract}

\section{Background}

T-cell acute lymphoblastic leukemia (T-ALL) accounts for $15 \%$ of newly diagnosed ALL cases in children and $20-25 \%$ of ALL cases in adults $[1,2]$. Overall, these are aggressive malignancies that do not respond well to chemotherapy and have a poorer prognosis than their B-cell counterparts [3]. The development of targeted therapies, including monoclonal antibodies and gene therapy, continues. Small interfering RNA (siRNA) is a promising gene-targeting agent that has shown great potential, particularly in the field of cancer treatment [4-6].

The B-cell chronic lymphocytic leukemia (CLL)/lymphoma 11B $(B C L 11 B)$ gene plays a crucial role in T-cell development, differentiation, and proliferation [7], and altered expression, mutation, disruption, or rearrangement of $B C L 11 B$ have been associated with $\mathrm{T}$-cell

\footnotetext{
* Correspondence: yangqiuli@hotmail.com

${ }^{1}$ Institute of Hematology, Medical College, Jinan University, Guangzhou, 510632, PR China

Full list of author information is available at the end of the article
}

malignancies [8-11]. BCL11B over-expression has been observed primarily in $\mathrm{T}$-cell malignancies $[8,12]$. $B C L 11 B$ has been hypothesized to act as a tumor suppressor gene $[9,13]$, but its precise function remains unclear.

BCL2-like 1 (BCL2L1; $B c l-x L)$ is similar to Bcl-2 because it restrains the apoptosis induction of multiple stimuli, and is a key factor in the terminal step of apoptosis regulation. Studies have shown that BCL2L1 participates in various protein-protein interactions, playing a role in inhibiting apoptosis. In the endogenous apoptosis pathway, BCL2L1 of the BCL-2 family inhibits apoptosis by blocking the translocation of Bax to the mitochondrial outer membrane [14]. cAMP-response element binding protein $(C R E B B P)$ plays a critical role in embryonic development, growth control, and homeostasis by coupling chromatin remodeling to transcription factor recognition. A CREBBP gene rearrangement with chromosomal translocation has been identified in acute myeloid leukemia [15,16] and over-expression of 
CREBBP was found in Jurkat cells. Additionally, enhancement of apoptotic cell death occurred in the presence of CREB1 siRNA [17]. Tumor necrosis factor (ligand) superfamily, member 10 (TNFSF10; TRAIL) is a tumor necrosis factor superfamily member, and induces apoptosis through its interaction with death receptors. BCL-2 family genes and TNFSF10 probably act together through crosstalk between the intrinsic and death receptor-mediated apoptosis pathways [18]. Secreted phosphoprotein 1 (SPP1) is also known as OPN and its abnormal activation can stimulate tumor growth, invasion, angiogenesis, and immune suppression, with wideranging effects on cell proliferation, apoptosis, differentiation, and migration $[19,20]$.

Previous studies $[21,22]$ showed that the inhibition of $B C L 11 B$ expression by siRNA selectively inhibited proliferation and effectively induced apoptosis in human $\mathrm{T}$-cell acute lymphoblastic leukemia (T-ALL) cell lines (Jurkat, Molt-4). Additionally, global gene expression profiling revealed that $B C L 11 B$ siRNA-mediated cell apoptosis may be related to BCL-2 family genes of the mitochondrial pathway, and the TRAIL (TNFSF10) gene of the death receptor signaling pathway [22], furthermore, in our previous study, the genes (SPP1 and $C R E B B P$ ) of the TGF- $\beta$ pathway (unpublished data). Little is known about the expression pattern of these genes in T-ALL. Thus, analyzing the expression pattern of these genes in malignant $\mathrm{T}$-cells is important because $B C L 11 B$ disruption and disturbed expression may contribute to the development of $\mathrm{T}$-cell malignancies in humans [8]. In the present study, we further analyzed expression levels of TNFSF10, BCL2L1, SPP1, and $C R E B B P$, and their correlation with $B C L 11 B$ in male patients with T-ALL, to clarify the role of $B C L 11 B$ in T-cell malignancies.

\section{Methods \\ Samples}

Nine newly diagnosed T-ALL patients (male, 6-28 years old; median age, 20 years; white blood cell count (WBC), $1.8-293.5 \times 10^{9} / \mathrm{L}$; bone marrow blast percentage: 65-93\%; were recruited. The diagnosis of T-ALL was based on cytomorphology, immunohistochemistry, and cytoimmunological analysis. Peripheral blood mononuclear cells (PBMCs) from nine healthy volunteers served as controls (five males and four females, 20-45 years old; median age, 28 years). Peripheral blood was collected by heparin anticoagulation and PBMCs were separated using the Ficoll-Hypaque gradient centrifugation method. The percentage of CD3+cells in PBMCs were detected, there are $75.30 \pm 26.77 \%$ (range 21.2 97.8\%) in PBMCs from T-ALL samples and $59.66 \pm$ 4.75\% (range 52.4-65.8\%) in PBMCs from healthy control samples.
All procedures were conducted in accordance with the guidelines of the Medical Ethics committees of the health bureau of Guangdong Province, PR China.

\section{RNA extraction and CDNA synthesis}

RNA was extracted using the Trizol kit (Invitrogen, Carlsbad, CA, USA) and reverse transcribed into the first-strand cDNA using random hexamer primers and the reverse transcriptase Superscript II Kit (Invitrogen), according to the manufacturer's instructions.

\section{Real-time quantitative reverse transcription-polymerase chain reaction ( $q R T-P C R$ )}

Quantitative detection of the BCL11B gene expression level in cDNA from PBMCs was performed using TaqMan real-time PCR. PCR was performed as described previously [8]. To precisely determine the copy numbers of $B C L 11 B$, a duplex vector, including a fragment of the $B C L 11 B$ and the $\beta 2$ microglobulin $(\beta 2 M)$ genes was constructed and used as a reference (the duplex vector was a gift from Prof. C.A. Schmidt, Ernst-Moritz-Arndt University Greifswald, Germany). Based on the DNA concentration, measured by spectrophotometry and confirmed by quantitative gel eletrophoresis, standard dilutions of the vector from $10^{7}$ to $10^{1}$ copies were prepared [8]. Briefly, PCR was performed in a $25-\mu \mathrm{L}$ total volume containing $2 \mu \mathrm{L}$ of cDNA, 25 pmol of each primer (BCL11B-f and BCL11B-b for BCL11B gene amplification; $\beta 2 \mathrm{Mf}$ and $\beta 2 \mathrm{Mb}$ for $\beta 2 M$ gene amplification), 10 nmol of each dNTP, $1.5 \mathrm{U}$ AmpliTaq Gold (Applied Biosystems, Branchburg, NJ, USA), 5 pmol of 6FAMTAMRA probe, and PCR buffer containing $4.5 \mathrm{mM}$ $\mathrm{MgCl}_{2}$. After an initial denaturation at $95^{\circ} \mathrm{C}$ for $5 \mathrm{~min}$, 50 cycles consisting of $95^{\circ} \mathrm{C}$ for $15 \mathrm{~s}$ and $64^{\circ} \mathrm{C}$ for $1 \mathrm{~min}$ were performed. Primers and probes for $B C L 11 B$ and $\beta 2 M$ gene amplification were synthesized by TIB Molbiol Co. (Berlin, Germany; Table 1).

The absolute amounts of $B C L 11 B$ and $\beta 2 M$ were measured in two independent assays and $B C L 11 B$ content per $100,000 \beta 2 M$ copies was calculated using the formula: $\mathrm{n}=100000 \times \mathrm{BCL} 11 \mathrm{~B} / \beta 2 \mathrm{M}$.

Expression levels of TNFSF10, BCL2L1, SPP1, $C R E B B P$, and the reference gene $\beta 2-M G$ were determined by SYBR Green I real-time PCR. Briefly, PCR was performed in a $25-\mu \mathrm{L}$ total volume containing $1 \mu \mathrm{L}$ of cDNA, $9 \mu \mathrm{L}$ of $2.5 \times$ SYBR Green mix (Tiangen, Beijing, PR China), and $10 \mu \mathrm{mol} / \mathrm{L}$ primer pairs. The following cycling conditions were used: initial denaturation at $95^{\circ} \mathrm{C}$ for $2 \mathrm{~min}$, followed by 44 cycles at $95^{\circ} \mathrm{C}$ for $15 \mathrm{~s}$, and $81^{\circ} \mathrm{C}$ (TNFSF10, SPP1, CREBBP, and $\beta-2-M G$ ) or $84^{\circ} \mathrm{C}$ (BCL2L1) for $1 \mathrm{~min}$. The relative amounts of the genes of interest and the $\beta 2 M$ reference gene were measured in two independent assays. The $2^{(-\Delta \Delta \mathrm{CT})}$ method was used to present the data of the genes of interest 
Table 1 Sequences of primers and probes for real-time PCR (TaqMan method)

\begin{tabular}{ccc}
\hline primers/probes & sequence & function \\
\hline$B C L 11 \mathrm{Bf}$ & $5^{\prime}$-CACCCCCGACGAGATGACCAC & forward primer \\
BCL11Bb & 5'-CGGCCCGGGCTCCAGGTAGATG & backward primer \\
BCL11Bp & 5'-6FAM-TCACCCACGAAAGGCATCTGTCCCAAGCA-TAMRA & probe \\
$\beta 2 \mathrm{Mf}$ & $5^{\prime}$-CTCGCGCTACTCTCTCTTCT & forward primer \\
$\beta 2 \mathrm{Mb}$ & 5'-TACATGTCTCGATCCCACTTAACTAT & backward primer \\
$\beta 2 \mathrm{Mp}$ & 5'-6FAM-CTCACGTCATCCAGCAGAGAATGGAAAGTCA-TAMRA & probe
\end{tabular}

relative to an internal control gene [23,24]. The efficiencies of real-time PCR for expression analysis of different genes were evaluated using diluted Molt- 4 cDNA $\left(1,5^{-1}\right.$, $\left.5^{-2}, 5^{-3}, 5^{-4}\right)$ as templates to construct relative standard curves. Additionally, the specific amplification of PCR products was analyzed by melting curve analysis and agarose electrophoresis. Primers used in the SYBR Green I real-time PCR for all four gene amplifications were synthesized by Shanghai Biological Engineering Technology Services Co., Ltd. (Table 2).

RT-PCR for TNFSF10, BCL2L1, SPP1, and CREBBP genes was performed using the same primers as described above, and the PCR products were sent to Shanghai Invitrogen Biotechnology Co. for DNA sequence analysis.

\section{Statistical analyses}

Independent-sample $t$-test analysis was used for the $B C L 11 B$ gene mRNA levels in different samples, while the Mann-Whitney $U$ test and Spearman's rank correlation analyses were used for non-normally distributed data using the SPSS 13.0 statistical software. Differences were considered statistically significant at $P<0.05$.

\section{Results}

\section{Over-expression of $B C L 11 B$ gene in T-ALL}

The expression level of $B C L 11 B$ mRNA in PBMCs from patients with T-ALL $\left(1821.81 \pm 1896.58\right.$ copies $/ 10^{5} \beta 2 M$ copies) was significantly higher than that from healthy controls $\left(259.71 \pm 182.72\right.$ copies $/ 10^{5} \beta 2 M$ copies; $t=$ 2.46; $P=0.039$; Figure 1$)$. PCR products from $\beta 2 M$ and

Table 2 Sequences of primers for real-time PCR (SYB Green I method)

\begin{tabular}{ccc}
\hline primers & \multicolumn{1}{c}{ sequence } & function \\
\hline TNFSF10 & 5'-GAGTATGAACAGCCCCT-3' & forward primer \\
TNFSF10 & 5'-GTTGCTTCTTCCTCTGGT-3' & backward primer \\
BCL2L1 & 5'-AAACTGGGTCGCATTGTGG-3' & forward primer \\
BCL2L1 & 5'-TCTCGGCTGCTGCATTGTTC-3' & backward primer \\
SPP1 & 5'-ACAGCCAGGACTCCATTGA-3' & forward primer \\
SPP1 & 5'-TCAGGTCTGCGAAACTTCTAG-3' & backward primer \\
CREBBP & 5'-CGGTTTCTCGGCGAATGAC-3' & forward primer \\
CREBBP & 5'-CATTTCCTATTCCTGGGTTGAT-3' & backward primer \\
\hline
\end{tabular}

$B C L 11 B$ genes were confirmed by $2.5 \%$ gel electrophoresis (Figure 2D, E).

\section{Expression of TNFSF10, BCL2L1, SPP1, and CREBBP genes in T-ALL}

The high amplification efficiency of the four genes of interest (TNFSF10, BCL2L1, SPP1, and CREBBP) was consistent with that of the $\beta 2 M$ reference gene. For example, the accurate standard curve graphs of BCL2L1 and $\beta_{2} M$ control gene amplification are illustrated in Figure $2 \mathrm{~A}$ and $2 \mathrm{~B}\left(\mathrm{r}^{2}=0.995\right)$. The amplification efficiencies of $B C L 2 L 1$ and the $\beta 2 M$ control gene were $95.30 \%$ and $95.16 \%$, respectively, and the melting curves are shown in Figure $2 \mathrm{C}$. PCR products from the $\beta 2 M$ control gene and genes of interest were confirmed using $2.5 \%$ gel electrophoresis (Figure 2D, E), followed by sequence confirmation (data not shown).

Relative expression levels of BCL2L1 mRNA (397.82 \pm $565.98 \%)$ and CREBBP mRNA (53.28 $\pm 39.21 \%)$ in patients with T-ALL were significantly higher than those from healthy controls (BCL2L1: $10.83 \pm 11.18 \%$; $C R E B B P: 20.80 \pm 13.50 \% ; P<0.05)$, whereas the relative expression levels of TNFSF10 and SPP1 mRNA showed no significant difference between T-ALL and healthy groups (Figure $2 \mathrm{~F}$ ).

In T-ALL patients, Spearman's rank correlation analyses revealed that the $B C L 11 B$ expression level was negatively

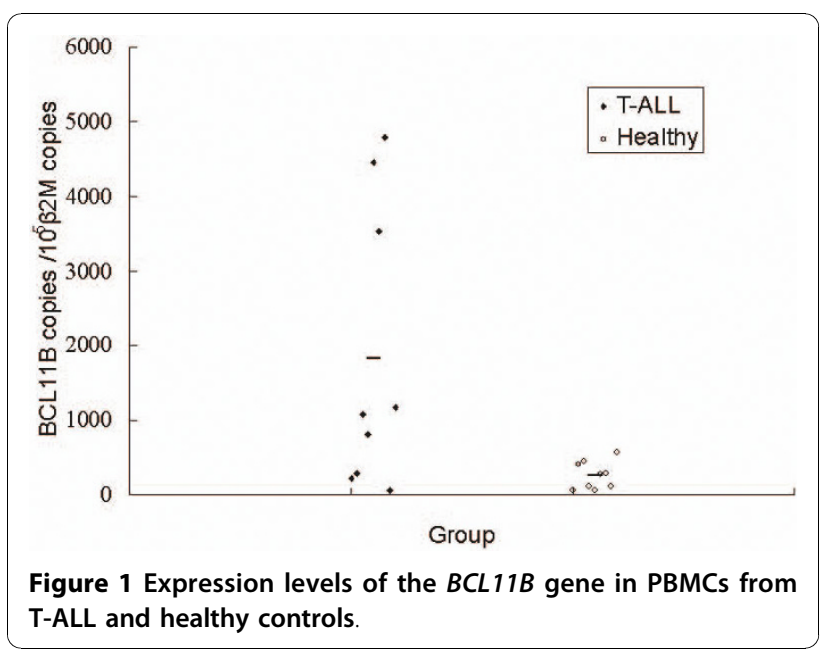




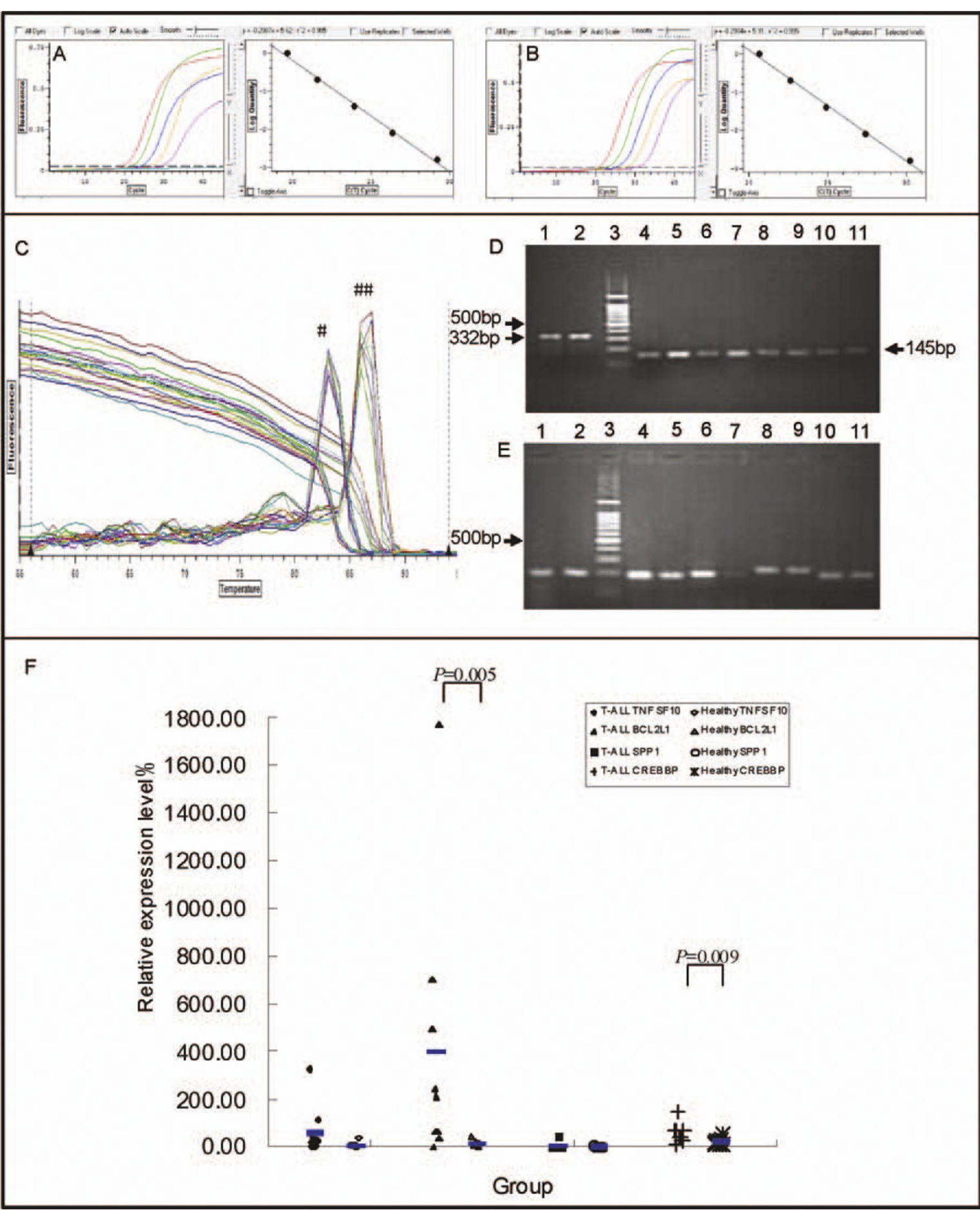

Figure 2 Features of the expression of TNFSF10, BCL2L1, SPP1, and CREBBP genes in T-ALL and healthy groups. A, B: ACcurate standard curve graphs of $B C L 2 L 1$ and the $\beta 2 M$ control gene are shown using diluted Molt- 4 CDNA as the template. The amplification efficiency of BCL2L1-related genes was more than $95 \%$, and consistent with the high amplification efficiency of the $\beta 2 M$ reference gene. C: Melting curves of the $B C L 2 L 1$ and $\beta 2 M$ genes from nine patients. \#: Specific peak of the $\beta 2 M$ reference gene begins at $81^{\circ} \mathrm{C}$. \#\#: Specific peak of the $B C L 2 L 1 \mathrm{gene}$ begins at $84^{\circ} \mathrm{C}$. D: PCR products of the $\beta 2 \mathrm{M}$ gene by $2.5 \%$ agarose gel electrophoresis analysis. The size of the PCR products of the $\beta 2 \mathrm{M}$ gene used for the $B C L 11 B$ reference is $332 \mathrm{bp}$ (line 1,2) and that used for the four genes of interest is $145 \mathrm{bp}$ (line 4-11). Line 3: DNA ladder. E: PCR products analyzed by 2.5\% agarose gel electrophoresis. Line 1-2: BCL11B (193bp), line 3: DNA ladder, line 4-5: BCL2L1 (202 bP), line 6-7: CREBBP (206 bp), line 8-9: SPP1 (241 bp), line 10-11: TNFSF10 (190 bp). F: Relative expression levels of the four genes of interest in T-ALL and healthy groups. 
correlated with the $B C L 2 L 1$ relative expression level $\left(r_{\mathrm{s}}=\right.$ -0.700; $P=0.036$; Figure $3 \mathrm{~A}$ ), and positively correlated with the SPP1 relative expression level $\left(r_{\mathrm{s}}=0.683 ; P=\right.$ 0.042 ; Figure 3B). The $B C L 11 B$ expression level did not exhibit an obvious correlation with TNFSF10 or CREBBP relative expression levels. No significant correlation was found between the $B C L 11 B$ gene and the other four genes of interest in the healthy controls.

\section{Discussion}

Increasing numbers of translocations involving the $B C L 11 B$ locus $[8,10,11]$ or high levels of $B C L 11 B$ mRNA expression in most T-ALL cases $[8,12]$ have been reported; however, the mechanism of $B C L 11 B$-mediated oncogenesis remains unknown. To clarify the role of $B C L 11 B$ in T-cell malignancies, we further analyzed the expression levels of TNFSF10, BCL2L1, SPP1, and $C R E B B P$ genes and their correlations with $B C L 11 B$ in patients with T-ALL and controls. Over-expression of the $B C L 11 B$ gene, as well as BCL2L1 and CREBBP mRNA, were characteristic features of T-ALL.

Recent evidence has suggested that multiple mechanisms may regulate the release of mitochondrial factors, some of which depend on the action of caspases. BCL2L1 may inactivate caspase- 8 by decreasing death-inducing signaling complex (DISC) formation in the plasma membrane, nucleus, and Golgi complex while diverting DISC formation to the mitochondria. The inhibitory effects of $B C L 2 L 1$ on DISC formation may play a significant role in protecting endothelial cells from hypoxia/reoxygenation (H/R)-induced cell death [25]. Thus, over-expression of the $B C L 2 L 1$ gene suggests that it might be related to the occurrence of T-ALL by defective regulation of apoptosis. During the process of T-ALL, over-expressed BCL2L1 is thought to suppress the activity of caspase-8; thus, as a kind of protection mechanism, the TNFSF10 gene of some patients is highly expressed, promoting caspase- 8 activity in response to this abnormal cell proliferation. However, the low expression level of SPP1 in untreated Molt-4 cells differed from the high expression levels found in mostly solid tumors [26]. Additionally, our findings indicated no significant difference in SPP1 gene expression in the TALL group. Comprehensive analysis revealed that T-ALL occurred in the presence of $B C L 11 B, B C L 2 L 1$, and $C R E B B P$ gene over-expression, which was closely related to blocking apoptosis of malignant $\mathrm{T}$ cell, whereas the TNFSF10 gene was also highly expressed in some patients, which may partly correct the imbalance.

Correlation analysis of $B C L 11 B$ in the T-ALL group revealed that the $B C L 11 B$ expression level was negatively correlated with that of $B C L 2 L 1$ (Bcl-xL), although over-expression of both genes was found in T-ALL samples. This suggested that BCL2L1 was affected by the $B C L 11 B$ gene in transcriptional regulation, and both participated in the same protein-protein interactions, acting as apoptosis regulators along with a competitive target protein downstream. In BCL11Bknockdown T-cell lines, when exposed to growth stimuli, $\mathrm{T}$ cells exhibit apoptosis in $\mathrm{S}$ phase with concomitant decreases in the cell-cycle inhibitor p27 and the anti-apoptotic protein $\mathrm{Bcl}-\mathrm{xL}$, due to transcriptional repression [13]. However, $B C L 11 B$ and $B C L 2 L 1$ protein levels in the T-ALL group still remain to be validated. Correlation analysis of $B C L 11 B$ in the T-ALL group revealed that the $B C L 11 B$ expression level was positively correlated with the relative $S P P 1$ expression level. The expression of SPP1 was significantly downregulated with $B C L 11 B$ silencing by RNA interference, suggesting that the SPP1 gene may be a target of the $B C L 11 B$ gene in transcriptional regulation (unpublished data). SPP1 gene silencing in vitro significantly increased mitochondrial cytochrome $c$ release, and the
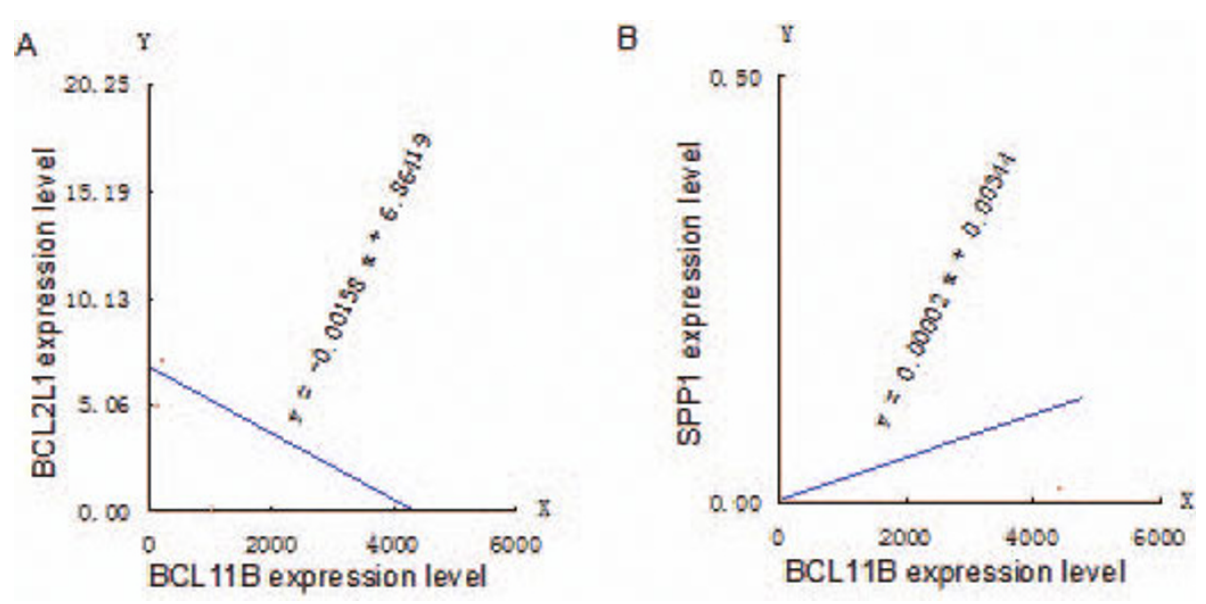

Figure 3 Linear correlation analyses of the $B C L 11 B$ and $B C L 2 L 1$ genes (A) and SPP1 gene (B) in T-ALL samples. 


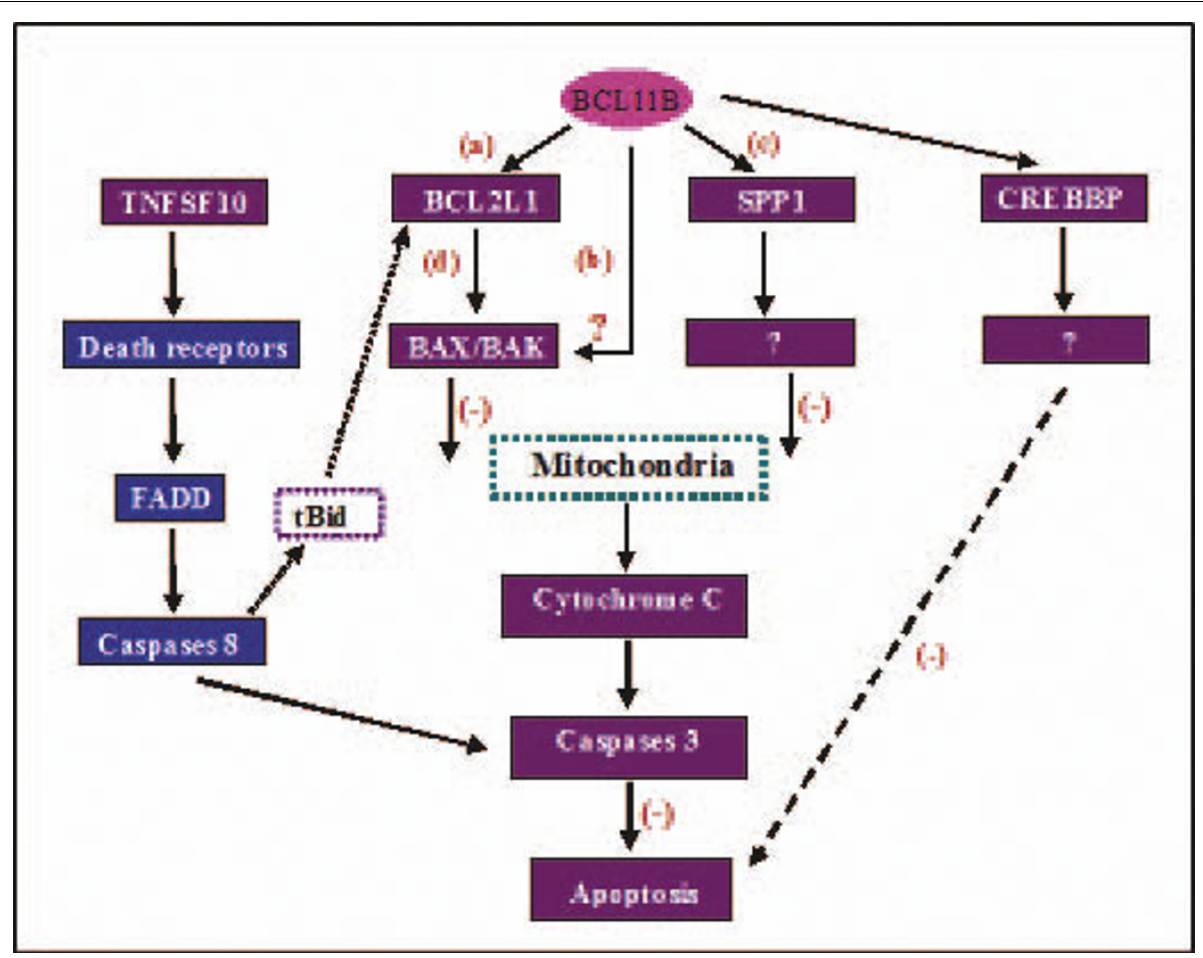

Figure 4 Schematic representation of the regulatory network of apoptosis in $B C L 11 B$ and its related genes. (a) $B C L 2 L 1$ is affected by the $B C L 11 B$ gene in transcriptional regulation. $(b, d) B C L 11 B$ and $B C L 2 L 1$ participate in the same protein-protein interactions, along with competitive downstream target proteins. $B C L 2 L 1$ (BCl-XL) normally interferes with the mitochondrial programmed cell death pathway by sequestering proapoptotic proteins such as BCL2-associated $\times$ protein $(B A X)$ and BCL2-antagonist/killer 1 (BAK1; BAK), suggesting that BAX/BAK may be competitive target proteins downstream of $B C L 11 B$. (c) The SPP1 gene may be a target of the BCL11B gene in transcriptional regulation: it plays a consistent role in anti-apoptotic effects with the BCL11B gene by decreasing mitochondrial cytochrome $c$ release.

inhibitory action of the Wnt target gene osteopontin (SPP1) on mitochondrial cytochrome $c$ release determines renal ischemic resistance [27]. Thus, the SPP1 gene may play a consistent role in anti-apoptotic effects with the $B C L 11 B$ gene, by decreasing mitochondrial cytochrome $c$ release. The hypothetical regulatory network of apoptosis in $B C L 11 B$ and related genes is shown in Figure 4. However, the role of the SPP1 gene in $\mathrm{T}$-cell malignancies is unclear, because low expression of SPP1 was detected in T-ALL.

\section{Conclusions}

The expression pattern of the $B C L 11 B$ gene and four of its related genes (TNFSF10, BCL2L1, SPP1, and $C R E B B P$ ) was characterized in T-ALL. Over-expression of BCL11B may play a role in anti-apoptosis in T-ALL cells through up-regulation of its downstream genes BCL2L1 and CREBBP.

\section{Acknowledgements}

The project was sponsored by grants from National Natural Science Foundation of China (No. 30771980), the Fundamental Research Funds for the Central Universities (No. 21610604) and the Guangdong Science \& Technology Project (No. 2007B030703008; and 2009B050700029).

\section{Author details}

${ }^{1}$ Institute of Hematology, Medical College, Jinan University, Guangzhou, 510632, PR China. Department of Hematology, Guangdong General Hospital (Guangdong Academy of Medical Sciences), Guangzhou, 510080, PR China.

${ }^{3}$ Key Laboratory for Regenerative Medicine of Ministry of Education, Jinan University, Guangzhou, 510632, PR China.

\section{Authors' contributions}

YQL made contributions to conception and design laboratory study. $\mathrm{XH}$, $S H C, Q S, L J Y$, and BL performed the laboratory technique process and the laboratory analyses. LYZ, SXG and XD were responsible of the patient's treatment and carried out acquisition of clinical data. YQL and $\mathrm{XH}$ coordinated the study and helped to draft the manuscript. All authors read and approved the final manuscript.

\section{Competing interests}

The authors declare that they have no competing interests.

Received: 19 October 2010 Accepted: 16 November 2010 Published: 16 November 2010

\section{References}

1. Rivera GK, Crist WM: Acute lymphoblastic leukemia. In Principles and Practice of Hematology. Blood Edited by: Handin Rl, Stossel TP, Lux SE 1995, 743-759.

2. Uckun FM, Sensel MG, Sun L, Steinherz PG, Trigg ME, Heerema NA: Biology and treatment of childhood T-lineage acute lymphoblastic leukemia. Blood 1998, 91:735-746.

3. Morris JC, Waldmann TA, Janik JE: Receptor-Directed Therapy of T-Cell Leukemias and Lymphomas. J Immunotoxicol 2008, 5:235-248. 
4. Oh YK, Park TG: siRNA delivery systems for cancer treatment. Adv Drug Deliv Rev 2009, 61:850-862.

5. Devi RS: siRNA-based approaches in cancer therapy. Cancer Gene Therapy 2006, 13:819-829.

6. Whitehead KA, Langer R, Anderson DG: Knocking down barriers: Advances in siRNA delivery. Nat Rev Drug Discov 2009, 8:129-138.

7. Liu P, Keller JR, Ortiz M, Tessarollo L, Rachel RA, Nakamura T, Jenkins NA Copeland NG: Bcl11a is essential for normal lymphoid development. Nat Immunol 2003, 4:525-532.

8. Przybylski GK, Dik WA, Wanzeck J, Grabarczyk P, Majunke S, MartinSubero Il, Siebert R, Dölken G, Ludwig WD, Verhaaf B, van Dongen JJ, Schmidt CA, Langerak AW: Disruption of the BCL11B gene through inv 14 q11.2q32.31 results in the expression of BCL11B-TRDC fusion transcripts and is associated with the absence of wild-type BCL11B transcripts in TALL. Leukemia 2005, 19:201-208.

9. Karlsson A, Nordigården A, Jönsson Jl, Söderkvist P: Bcl11b mutations identified in murine lymphomas increase the proliferation rate of hematopoietic progenitor cells. BMC Cancer 2007, 7:195.

10. Strehl $S$, Konig M, Spath K: Juxtaposition of the BCL11B gene to a novel region at $17 \mathrm{q}$ by a $\mathrm{t}(14 ; 17)(\mathrm{q} 32 ; \mathrm{Q} 21)$ in childhood T-Cell lymphoblastic lymphoma [abstract]. Blood 2007, 110:101B.

11. Su XY, Della-Valle V, Andre-Schmutz I, Lemercier C, Radford-Weiss I, Ballerini P, Lessard M, Lafage-Pochitaloff M, Mugneret F, Berger R, Romana SP, Bernard OA, Penard-Lacronique V: HOX11L2/TLX3 is transcriptionally activated through T-cell regulatory elements downstream of $\mathrm{BCL11B}$ as a result of the $\mathrm{t}(5 ; 14)$ (q35;q32). Blood 2006, 108:4198-4201.

12. Oshiro A, Tagawa H, Ohshima K, Karube K, Uike N, Tashiro Y, Utsunomiya A, Masuda M, Takasu N, Nakamura S, Morishima Y, Seto M: Identification of subtype-specific genomic alterations in aggressive adult T-cell leukemia/ lymphoma. Blood 2006, 107:4500-4507.

13. Kamimura K, Mishima Y, Obata M: Lack of Bcl11b tumor suppressor results in vulnerability to DNA replication stress and damages. Oncogene 2007, 26:5840-5850.

14. Breckenridge $D G$, Xue $D$ : Regulation of mitochondrial membrane permeabilization by BCL-2 family proteins and caspases. Curr Opin Cell Biol 2004, 16:647-652.

15. Borrow J, Stanton VP Jr, Andresen JM, Becher R, Behm FG, Chaganti RS, Civin Cl, Disteche C, Dubé I, Frischauf AM, Horsman D, Mitelman F, Volinia S, Watmore AE, Housman DE: The translocation $t(8 ; 16)(p 11 ; 13)$ of acute myeloid leukaemia fuses a putative acetyltransferase to the CREBbinding protein. Nature Genet 1996, 14:33-41.

16. Giles RH, Dauwerse JG, Higgins C, Petrij F, Wessels JW, Beverstock GC, Döhner H, Jotterand-Bellomo M, Falkenburg JH, Slater RM, van Ommen GJ, Hagemeijer A, van der Reijden BA, Breuning MH: Detection of CBP rearrangements in acute myelogenous leukemia with $\mathrm{t}(8 ; 16)$. Leukemia 1997, 11:2087-2096.

17. Caravatta L, Sancilio S, di Giacomo V, Rana R, Cataldi A, Di Pietro R: PI3-K/ Akt-dependent activation of CAMP-response element-binding (CREB) protein in Jurkat T leukemia cells treated with TRAIL. J Cell Physiol 2008, 214:192-200

18. Adams JM, Cory S: The BCl-2 apoptotic switch in cancer development and therapy Bcl-2 apoptotic switch in cancer. Oncogene 2007, 26:1324-1337.

19. Standal $T$, Borset $M$, Sundan A: Role of osteopontin in adhesion, migration, cell survival, and bone remodeling. Exp Oncol 2004, 26:179-184.

20. Rangaswami $\mathrm{H}$, Bulbule A, Kundu GC: Osteopontin: role in cell signaling and cancer progression. Trends Cell Biol 2006, 16:79-87.

21. Huang $X$, Chen S, Yang L, Chen SH, Zhou YB, Schmidt CA, Li YQ: Effects of down-regulating $B C L 11 B$ expression on the proliferation, apoptosis and global gene expression profiling of Molt-4 cells [Abstract]. Blood 2009, 114:4505.

22. Grabarczyk P, Przybylski GK, Depke M, Völker U, Bahr J, Assmus K, Bröker BM, Walther R, Schmidt CA: Inhibition of BCL11B expression leads to apoptosis of malignant but not normal mature T cells. Oncogene 2007, 26:3797-3810.

23. Livak KJ, Schmittgen TD: Analysis of relative gene expression data using real-time quantitative PCR and the 2(-Delta Delta C(T)) Method. Methods 2001, 25:402-408.
24. Pfaffl MW, Horgan GW, Dempfle L: Relative expression software tool (REST) for group-wise comparison and statistical analysis of relative expression results in real-time PCR. Nucleic Acids Res 2002, 30:e36.

25. Wang X, Zhang J, Kim HP: BCl-XL disrupts death-inducing signal complex formation in plasma membrane induced by hypoxia/reoxygenation. FASEB J 2004, 18:1826-1833.

26. Rodrigues $L R$, Teixeira JA, Schmitt FL, Paulsson M, Lindmark-Mänsson H: The role of osteopontin in tumor progression and metastasis in breast cancer. Cancer Epidemiol Biomarkers Prev 2007, 16:1087-1097.

27. Viñas JL, Sola A, Jung M, Mastora C, Vinuesa E, Pi F, Hotter G: Inhibitory action of Wnt target gene osteopontin on mitochondrial cytochrome $c$ release determines renal ischemic resistance. Am J Physiol Renal Physiol 2010, 299:F234-242.

doi:10.1186/1756-8722-3-44

Cite this article as: Huang et al: Analysis of the expression pattern of the $B C L 11 B$ gene and its relatives in patients with T-cell acute lymphoblastic leukemia. Journal of Hematology \& Oncology 2010 3:44.

\section{Submit your next manuscript to BioMed Central and take full advantage of:}

- Convenient online submission

- Thorough peer review

- No space constraints or color figure charges

- Immediate publication on acceptance

- Inclusion in PubMed, CAS, Scopus and Google Scholar

- Research which is freely available for redistribution

Submit your manuscript at www.biomedcentral.com/submit
Ciomed Central 